\title{
Comparative observations of biological specimens, especially DNA and filamentous actin molecules in atomic force, tunnelling and electron microscopes
}

\author{
Etienne Delain $\left({ }^{1}\right)$, Alain Fourcade $\left({ }^{1}\right)$, Jean-Claude Poulin $\left({ }^{2}\right)$, Agnès Barbin $\left({ }^{1}\right)$, Dominique \\ Coulaud $\left({ }^{1}\right)$, Eric Le Cam $\left({ }^{1}\right)$ and Emmanuel Paris $\left({ }^{3}\right)$ \\ ( $\left.{ }^{1}\right)$ Laboratoire de Microscopie cellulaire et moléculaire, URA 147 du Centre National de la \\ Recherche Scientifique (CNRS), Institut Gustave Roussy, F-94805 Villejuif Cedex, France \\ $\left({ }^{2}\right)$ Laboratoire de Synthèse asymétrique, URA 1497 du Centre National de la Recherche Scien- \\ tifique (CNRS), Bâtiment 420, F-91405 Orsay Cedex, France \\ $\left({ }^{3}\right)$ Instrumat, $\mathrm{BP} \mathrm{n}^{\circ} 86, \mathrm{~F}-91943$ Les Ulis Cedex A, France
}

(Received 21 December 1992, accepted 6 January 1993)

\begin{abstract}
Résumé. - Cet article décrit les conditions permettant d'adsorber sur du mica du virus de la Mosaique du Tabac (TMV), des protéines ou de l'ADN double-chaîne, pour leur observation en Microscopie de Force Atomique (AFM). L'optimisation des conditions d'étalement de l'ADN a été faite à l'aide de répliques observées dans un microscope électronique à transmission (TEM); la présence d'ions $\mathrm{Mg}^{2+}$ ou $\mathrm{Ca}^{2+}$ et un lavage avec une solution diluee de sels d'uranium sont nécessaires pour obtenir des résultats reproductibles. Les observations ont été faites dans l'air ou dans un liquide avec un NanoScope équipé de pointes commerciales en $\mathrm{Si}_{3} \mathrm{~N}_{4}$ ou en silicium. Si la longueur de l'ADN circulaire est très proche de sa valeur théorique, la largeur apparente de toutes les molécules observées est bien superieure à leur taille réelle, du fait du relativement grand rayon de courbure de la pointe. Les meilleurs résultats ont été obtenus en milieu liquide (eau ou propanol) avec des pointes en silicium, ou en utilisant le nouveau "TappingMode ${ }^{\mathrm{TM}}$ ". Des échantillons métallisés, ainsi que la face des répliques qui était en contact avec le mica, ont été observés dans un Microscope à effet Tunnel (STM) et ont donné des résultats comparables à ceux obtenus en AFM dans les meilleures conditions.
\end{abstract}

\begin{abstract}
The conditions for the adsorption onto mica of Tobacco Mosaic Virus (TMV), proteins or double-stranded DNA, for their observation with an Atomic Force Microscope (AFM) are described. The optimization of adsorption conditions for DNA spreading out was achieved by observing replicas with a transmission electron microscope (TEM); $\mathrm{Mg}^{2+}$ or $\mathrm{Ca}^{2+}$ ions in the DNA solution and its washing out with diluted uranium salts are necessary to provide reproducible results. Observations have been done in air or in liquids in a NanoScope equipped with commercial $\mathrm{Si}_{3} \mathrm{~N}_{4}$ or silicium tips. Contour length measurements are very close to the theoretical values; however the apparent width of all the observed molecules is much greater than their actual diameter, due to the relatively large radius of curvature of the tips. The best results were obtained with sharper silicium tips used in a propanol- or water-containing liquid stage, or by imaging with the new "TappingMode ${ }^{\mathrm{TM}}$ ". Specimens, rendered conductive by metallization, or the mica facing side of replicas were observed in a Scanning Tunnelling Microscope (STM) with results similars to the best AFM observations.
\end{abstract}




\section{Introduction.}

Atomic resolution has been described on Scanning Tunnelling Microscope (STM) images of DNA molecules adsorbed on the conducting highly oriented pyrolytic graphite (HOPG) [reviews in 1, 2]. However the HOPG surface is now considered to be at the origin of images that mimic the DNA structure [3,4], so data concerning DNA visualization on HOPG have to be considered with caution. The Atomic Force Microscope (AFM), for which no conductivity is needed, is often used to observe organic or biological molecules deposited on the surface of mica [reviews in 5-7]. $\mathbf{R e}-$ cently, an increasing number of papers have shown images of non ambiguous double-stranded DNA [8-17], RNA [18] and even single-stranded DNA [16, 17] molecules, but the published images never show atomic resolution, mainly because styli are not sharp enough.

Only a few papers have provided AFM or STM images which actually represent a known structure, by showing test objects such as Tobacco Mosaic Virus (TMV) [19], or polymerized protein molecules, either in a linear, helical [20-23] or a 2D arrangement [24-26].

All biological objects, especially DNA molecules, either free or in association with proteins, need to be firmly attached to the support and randomly distributed so that biologically relevant phenomena can be observed and selected with Transmission Electron Microscopes (TEM) [27], AFM or STM. The adsorption of DNA molecules onto mica was first introduced by Hall [28] and has been traditionally used for deep-etching cryotechniques [29]. Various grafting agents, including $\mathrm{Mg}^{2+}$ have been used to facilitate DNA binding to mica for electron microscopy studies [reviews in 30, 31]. More recently, this procedure was extended to the attachment of nucleic acid molecules [8-14, 16], or DNA-protein complexes [10, 23] onto mica substrates for AFM or more rarely STM observation. We have tested the conditions under which biological objects or molecules (TMV, large proteins, including actin filaments, and double-stranded DNA) can be deposited onto mica in a reproducible manner for their visualization with AFM and STM, using different scanning modes, and systematically compared these images with those obtained with the traditional TEM.

\section{Material and methods.}

2.1 MATERIAL. - Human plasma alpha 2-Macroglobulin ( $\alpha 2 \mathrm{M})$ complexed with chymotrypsin was prepared and observed in TEM as already described [32]. Multicatalytic proteinase from Thermoplasma acidophilum was a gift from W. Baumeister [33]. TMV was a gift from J. Witz (Strasbourg, France). These samples have to be diluted in suitable buffers or water to get an adequate concentration on a hydrophilic glow-discharged carbon-coated grid, or on non pretreated cleaved mica. Similar ranges of concentrations were suitable for both types of support. Proteins and TMV preparations were processed for TEM observation as already described for $\alpha 2 \mathrm{M} \mathrm{[32].}$

Rabbit muscle actin was kindly provided by A. Bremer (M.E. Müller Institute, Biocentrum, Basel, Switzerland). The filaments were assembled and stabilized at a concentration of $1 \mathrm{mg} / \mathrm{ml}$ in $2.5 \mathrm{mM}$ imidazole, $\mathrm{pH} 7.4,0.2 \mathrm{mM} \mathrm{CaCl}_{2}, 2 \mathrm{mM} \mathrm{MgCl}, 50 \mathrm{mM} \mathrm{KCl}, 0.2 \mathrm{mM} \mathrm{NaATP}$ and $50 \mathrm{mM}$ phalloidin, according to [34]. The stock solution was diluted 1/20 in this buffer for direct adsorption onto mica.

Double-stranded DNA was a $0.5 \mu \mathrm{g} / \mathrm{ml}$ solution of pBR322 relaxed plasmids in very diluted Tris buffer solution ( $80 \mu \mathrm{M}, \mathrm{pH} 7.5)$.

Red muscovite mica pieces (about $2 \times 3 \mathrm{~cm}$ ) were obtained from an insulator manufacturer (Acim Jouanin, Paris, France). Other mica samples were purchased from various electron microscopy suppliers.

HOPG was purchased from Le Carbone Lorraine (Genevilliers, France). 


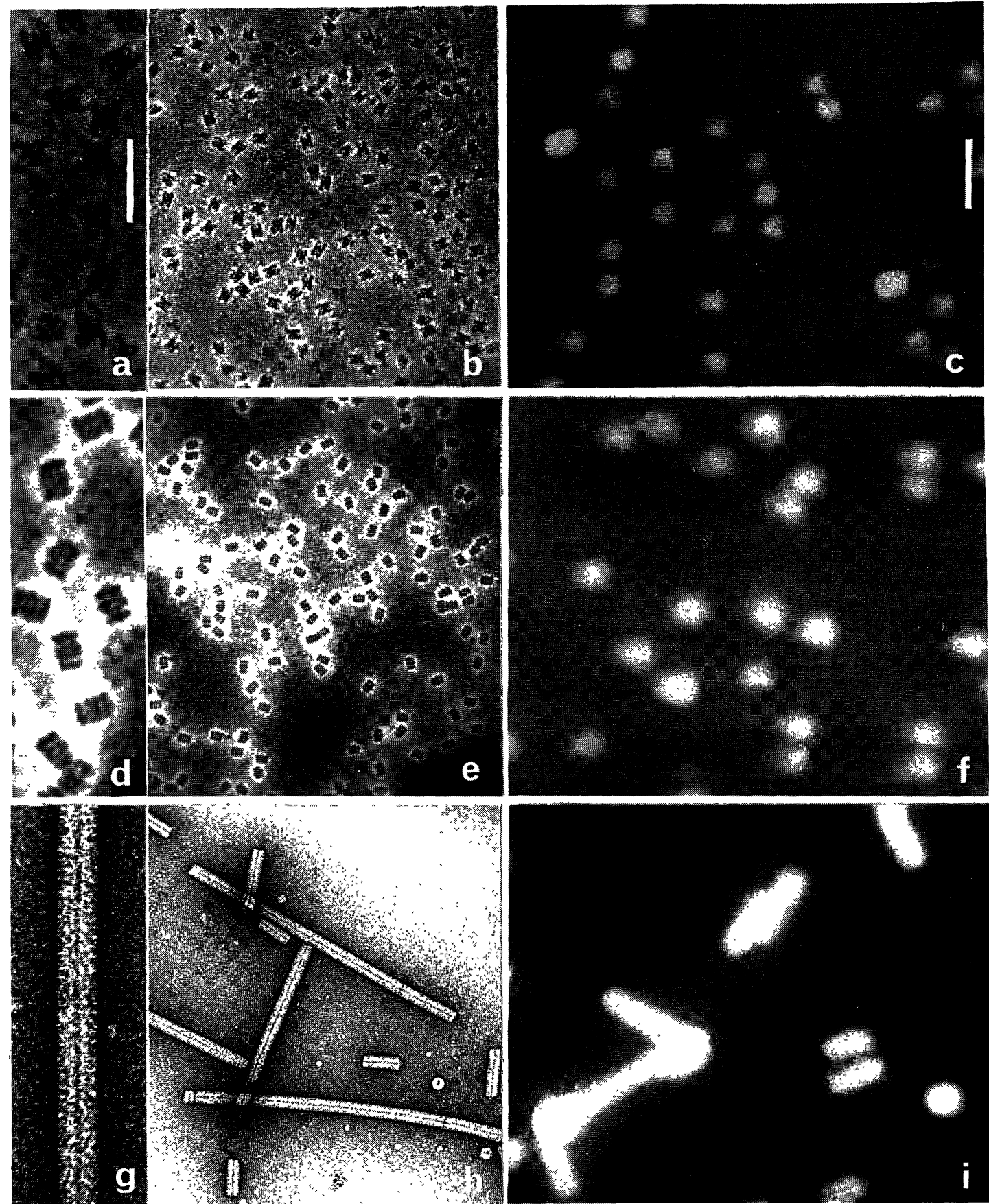

Fig. 1. - TEM and AFM observation of globular proteins and TMV. a \& b) Transmission Electron Micrograph (TEM) of negatively stained human alpha2-macroglobulin observed with a Zeiss 902 in Electron Spectroscopic Imaging. The structure of the molecules is visible at high magnification (a). The large field (b) is to compare the actual size of the molecules with their apparent size as seen in AFM (c). c) Observation of the molecules adsorbed onto mica, with a NanoScope II AFM in air (Digital Instruments $\mathrm{Si}_{3} \mathrm{~N}_{4}$ cantilever). Same magnification as that of $b$. $d$ \& e) TEM of multicatalytic proteinase observed as in a \& b. f) AFM image at the same magnification as that of e. $g \& h$ ) Tobacco Mosaic Virus observed in bright-field TEM. i) AFM image at the same magnification as that of $h$. The scales represent $40 \mathrm{~nm}(a, d \& g)$ or $100 \mathrm{~nm}(b, c, e$, f, h \& i). 
2.2 METHODS. - Three to five $\mu \mathrm{l}$ of protein or virus solution were deposited for $1 \mathrm{~min}$ onto cleaved mica pieces (trimmed to about $10 \times 10 \mathrm{~mm}$ ) at a concentration of about $10 \mu \mathrm{g} / \mathrm{ml}$. The actual distribution on the mica greatly depends on the concentration, the size of the biological object and the time allowed for adsorption. The excess solute was washed out with 4 drops of $0.2 \%$ uranyl acetate, then the mica was washed by floating it on the surface of 4 drops of water, drained and air dried.

A similar procedure was used for the DNA, except that the concentration of the aqueous uranyl acetate washing solutions ranged from 0.2 to $0.002 \%$ (w/v) (i.e. $5 \mathrm{mM}$ to $50 \mu \mathrm{M}$ ). An alternative procedure consisted in using a $0.2 \%$ solution in $50 \%$ ethanol.

Replicas were made in a MED 010 Balzers apparatus, with a electron gun for the evaporation of $\mathrm{Pt} / \mathrm{C}$ or $\mathrm{Pt} / \mathrm{Ir} / \mathrm{C}$ pellets disposed at the end of a carbon rod [35]. The different conditions of metallization are described later. Replicas for TEM observation were floated off the mica onto a water bath and deposited onto 300 mesh bare grids.

Some metallizations were made by evaporating a thick layer of $\mathrm{Pt} / \mathrm{Ir} / \mathrm{C}$ on the molecules adsorbed onto the mica. The metal deposit was then coated with collodion and the replica was floated off the mica and picked up with a glass coverslip which sticks to the upper surface of the replica. The rear surface of this replica which was facing the mica, was then accessible for AFM or STM examination as already described [7, 36, 37].

Replicas were observed by TEM with a Zeiss 902 in Electron Spectroscopic Imaging (ESI) obtained by selecting a band width of $20 \mathrm{eV}$ inelastic electrons in the range of $60-120 \mathrm{eV}$ energy losses. ESI provides very contrasted images with a reverse contrast $[38,39]$.

AFM observations were done in the repulsive or in the deflection mode (constant pressure $=10^{-8}$ to $10^{-9} \mathrm{~N}$ ), with a NanoScope II equipped with a $\mathrm{Si}_{3} \mathrm{~N}_{4}$ cantilever (spring constant $0.58 \mathrm{~N} / \mathrm{m}$ ) from Digital Instruments (Santa Barbara, CA, USA). Some experiments were done in the same conditions with a NanoScope III equipped with a sharper Si cantilever (spring constant $20 \mathrm{~N} / \mathrm{m}$ ) from Nanoprobe (Wetzlar-Blankenfeld, Germany) [40], in the repulsive or in the friction mode (constant pressure $=10^{-10} \mathrm{~N}$ ) in the stage designed for observation in liquids. The samples were first observed in air then in a liquid injected in the stage, either water for actin or propanol for DNA. A few observations were made with a NanoScope III fitted to operate in the new "TappingMode TM" [see European Microscopy and Analysis 19 (sept. 1992) p.3].

The STM was a NanoScope II equipped with electrochemically etched $\mathrm{Pt} / \mathrm{Ir}$ (80/20) lab-made tips, operating conditions being $0.3-0.5 \mathrm{nA}$ and $100-450 \mathrm{mV}$ in constant current mode.

\section{Results.}

\subsection{PROTEINS.}

TEM and AFM observations. - Comparative TEM and AFM images of two proteins: alpha 2macroglobulin and Multicatalytic Proteinase, and TMV are shown in figure 1. Besides the well known structure of these biological objects observed in TEM (Figs. 1a, b; d, e; g, h, respectively), the convolution of the traditional $\mathrm{Si}_{3} \mathrm{~N}_{4}$ tip with the molecules gives reproducibly broadened images of the molecular profiles (Figs. 1c, f, i, respectively).

With actin filaments (Fig. 2), which are much thinner than the preceding particles, much better images were obtained in AFM. Images obtained with the Si tip in air with a NanoScope III show fuzzy individual filaments (Fig. 2b), but sharper images were obtained when the specimen stage was filled with water (Figs. 2c, f, g). The drawback here is that protein stability is reduced after repeated scans. The apparent width of the actin filament $(50 \mathrm{~nm})$ is quite large compared to its actual size $(7 \mathrm{~nm})$ [34], as measured on electron micrographs (Figs. 2a, d, e). The periodicity of 
the actin filament is however rather faithfully obtained and very close to the value of $36 \mathrm{~nm}$ from crystallographic and TEM data. Much better images (apparent width $33 \mathrm{~nm}$ ) are obtained in the "TappingMode ${ }^{\mathrm{TM}}$ " in air, which does not destroy the molecules even after several scans (Fig. $2 \mathrm{~h}$ ). The observation of the rear surface of the thick replicas, which was facing the mica, reveals the molecules embedded in the metal film (Figs. 2i, j). Images obtained in the AFM repulsive mode show the rather low height of the molecules (Fig. 2i), and the friction mode (Fig. 2j) demonstrates the presence of the molecules which appear in reverse contrast, compared to that obtained in the repulsive mode.

STM observation of the back of such replicas is easier than that of shadowed specimens, since the surface facing the mica is flat, because the molecules are embedded in the metal deposit. With reversed contrast, the actin filaments exhibit an apparent width and depth of 10-20 nm and 6$14 \mathrm{~nm}$, respectively, which are still higher than TEM measurements, but smaller than that obtained in AFM (data not shown).

\subsection{DOUBLE-STRANDED CIRCULAR DNA.}

AFM observations. - The adsorption of plasmid DNA molecules onto untreated cleaved mica, from a solution containing $\mathrm{Mg}^{2+}$ or $\mathrm{Ca}^{2+}$ was easy and reproducible. This leads to very clean fields, which could be observed at low magnification in TEM, or with large scans up to $10 \mu \mathrm{m}$ in AFM, showing numerous unambiguously discernable circular DNA molecules (Fig. 3). The concentration range of magnesium acetate or magnesium chloride ( 0 to $2 \mathrm{mM}$ ) added to the DNA solution was tested. Molecules were perfectly spread out for magnesium acetate concentrations between 2 and $0.4 \mathrm{mM}$ and badly spread out or collapsed below $0.3 \mathrm{mM}$. Among other divalent cations tested, calcium was unequalled when used in the same concentration range. With $\mathrm{Ca}^{2+}$, molecules appeared to be slightly more tensed than with $\mathrm{Mg}^{2+}$, i.e. with less apparent flexibility. Such an effect of cations on the flexibility and the curvature of DNA is well known [41]. Other cations $\left(\mathrm{Ni}^{2+}, \mathrm{Co}^{2+}, \mathrm{Mn}^{2+}, \mathrm{Zn}^{2+}\right)$ are less efficient than $\mathrm{Mg}^{2+}$ or $\mathrm{Ca}^{2+}$ for the adsorption of DNA onto mica, either because they need to be in a high concentration $(\geq 50 \mathrm{mM})$ and/or because they lead to entangled or distorted molecules. In our hands, $\mathrm{Al}^{3+}$ did not promote any adsorption, as seen in TEM on control replicas.

Mica pretreatment with $\mathrm{Mg}^{2+}$ salts was tested, found unsatisfying, and thus abandoned. If the $\mathrm{NaCl}$ concentration in the DNA solution is increased, then that of magnesium acetate should likewise be increased (for example $10 \mathrm{mM}$ magnesium acetate for $100 \mathrm{mM} \mathrm{NaCl}$ ). The presence of up to $80 \%$ formamide in the solution did not impair the quality of DNA spreading. This was used to see if it was possible to image single-stranded $\phi$ X174 or M13 DNA, and partially melted DNA molecules.

For a strong adsorption of DNA onto mica, it is important that excess solute be washed out with uranyl acetate solutions, as is the case for DNA adsorbed onto carbon films for TEM observation [27]. The results obtained with aqueous solutions ranging from 0.2 to $0.002 \%$ were just as good. Lower concentrations of uranyl salts, or water alone gave rise to entangled molecules. Molecules were also well spread out and highly contrasted when rinsed with $0.2 \%$ uranyl acetate in $50 \%$ ethanol. To compare these results obtained by adsorbing DNA onto mica with the help of divalent cations, DNA molecules were also adsorbed onto mica pieces pretreated with a glow-discharge in the presence of pentylamine, a routine procedure in the laboratory [27, 42]. This causes DNA molecules to spread out normally, but the backgrounds are dirty. Imaging such samples with the AFM was difficult as strong interactions were encountered between the tip and the specimen.

The importance of the recency of the mica cleavage seems to be a moot point as no significant difference was observed in DNA binding to mica when cleavage occurred 30 sec to several 

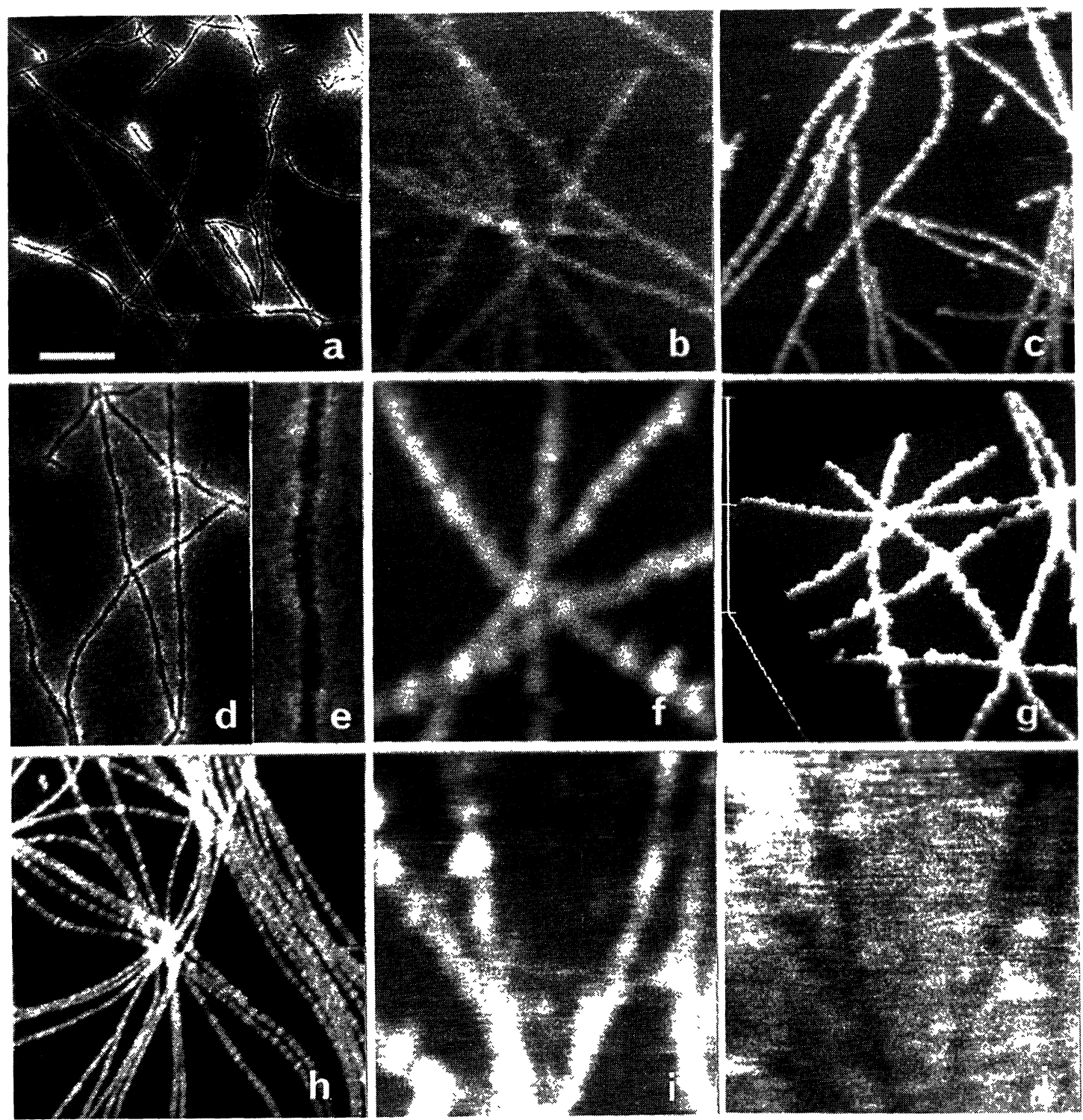

Fig. 2. - TEM and AFM observation of filamentous actin. a, d, e) TEM images of rabbit muscle actin filaments observed as described for Figs. 1a \& b. Note that a, b, c \& h are at the same magnification $(40,000)$ for an easier comparison between the apparent width of actin in the AFM images with that obtained in TEM. A 350,000 enlargement shows the $36 \mathrm{~nm}$ period and the $7 \mathrm{~nm}$ diameter (e). b) Observation in air of actin filaments adsorbed onto mica, with a NanoScope III AFM (Nanoprobe Si cantilever). c, f, g) Observation in water of the same sample, with a NanoScope III AFM (Nanoprobe Si cantilever). The high magnification (f) and the 3D representation (g, magnification about 50,000 ) clearly reveal the periodicity of the filaments. Note that $\mathrm{d}, \mathrm{f}, \mathrm{i} \& \mathrm{j}$ are at the same magnification $(100,000)$. h) Thinner filaments and a better resolution are obtained with a NanoScope III operated in the "TappingMode ${ }^{\mathrm{TM}}$ " in air. i \& j) Observation in air with a Si tip of the rear face view of a Pt/Ir/C replica, showing the contact plane of the molecules with the mica. Repulsive mode (i), friction mode on the same field (j). The scale represents $250 \mathrm{~nm}$ (a, b, c \& h), $100 \mathrm{~nm}$ $(\mathrm{d}, \mathrm{f}, \mathrm{i} \& \mathrm{j})$ or $30 \mathrm{~nm}(\mathrm{e})$. 


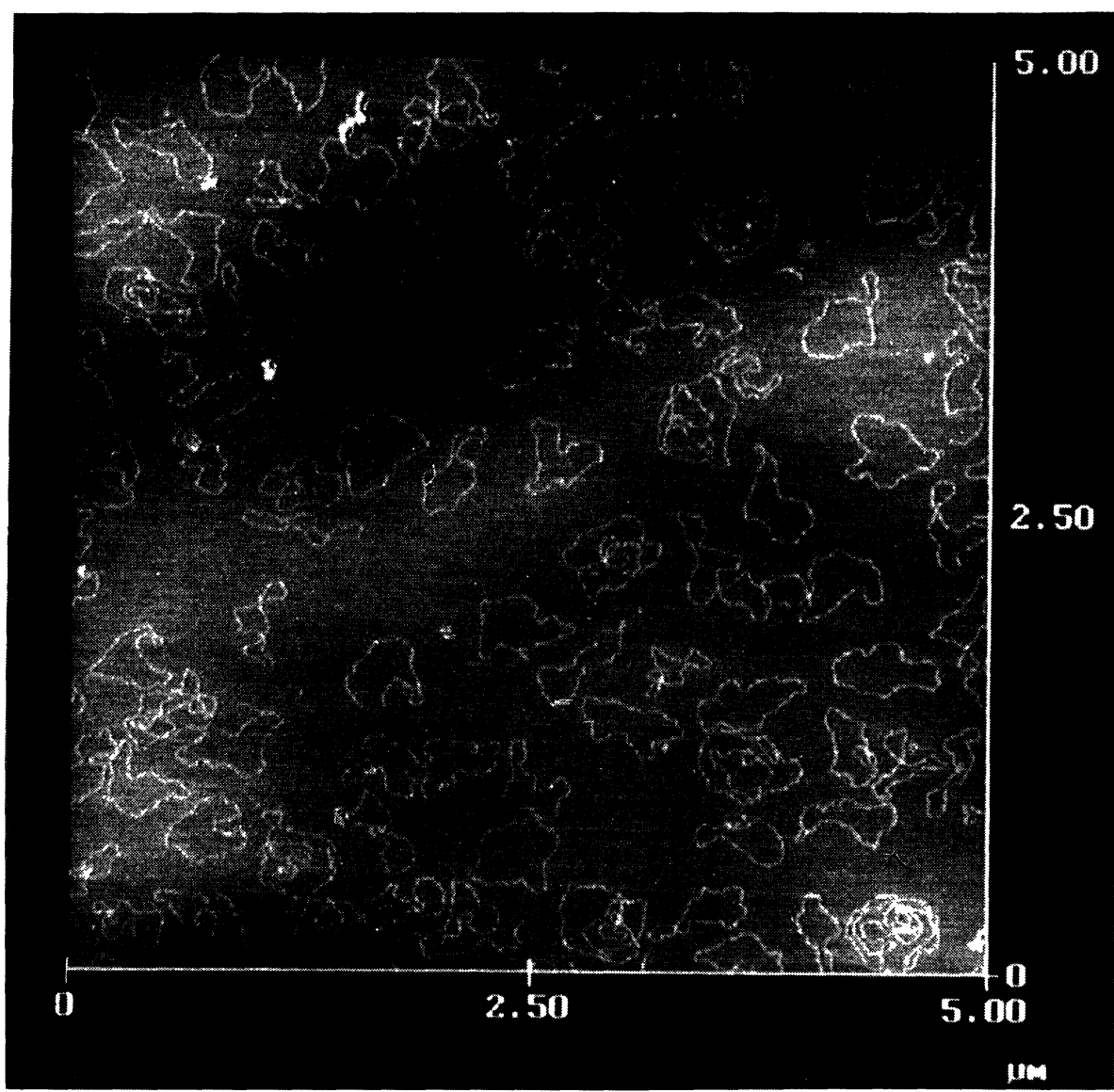

Fig. 3. - AFM of DNA. Representative field $(5 \times 5 \mu \mathrm{m})$ of pBR322 double-stranded circular DNA molecules adsorbed onto non pretreated mica with the help of calcium ions, and washed with $50 \mu \mathrm{M}$ of aqueous uranyl acetate. Observation in air with a NanoScope III equipped with a Nanoprobe Si tip.

weeks prior. This was confirmed by the similarly good results obtained when cleaving the mica into a droplet of DNA solution. Thus, we used mica pieces which were cleaved from about one hour to several days prior. They were kept in a Petri dish in the air, and no particular precautions were taken to protect them from humidity or contamination due to the surrounding atmosphere. This absence of deterioration of the adsorption properties is quite puzzling, for it is known that once cleaved, mica is rapidly contaminated with water and air gases. Several mica samples obtained from an insulator manufacturer or electron microscopy suppliers were tested and gave similar good results. The relative humidity $(\mathrm{RH})$ conditions when observing the molecules were not controlled since no problem was encountered whatever the $\mathrm{RH}$. It was however noted that freshly prepared samples observed in air were fragile under the tip, and that samples kept in air for weeks has a tendency to get a dirty background.

DNA molecules bound to the mica were observed in different conditions and compared, at the same magnification, to the replicas seen in TEM (Fig. 4a). Figure 4b shows the deflection mode which provides a relief image, compared to the normal repulsive mode (Fig. 4c), which 


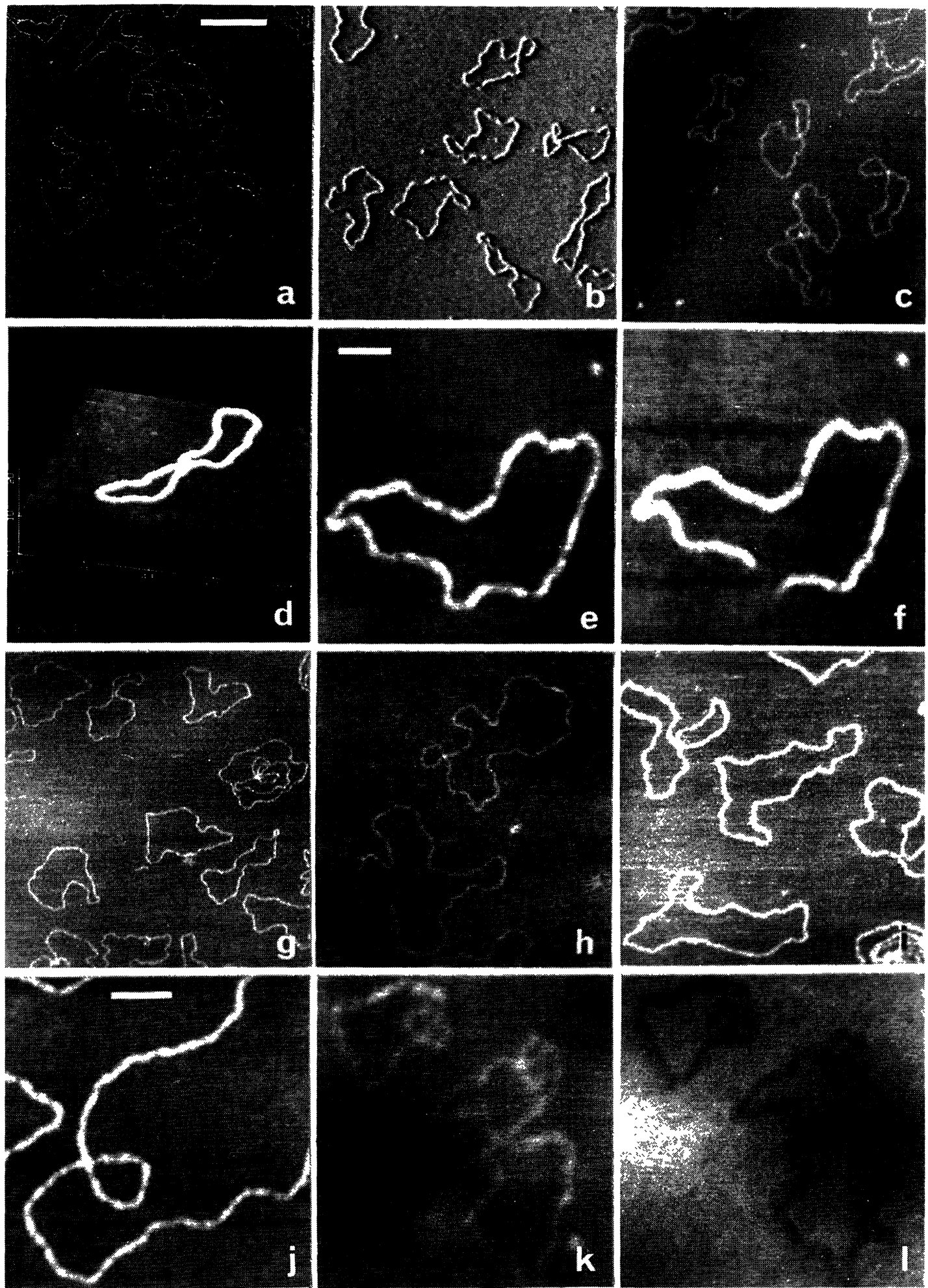

Fig. 4. - (See next page) 
can also be presented in 3D (Fig. 4d) for better visualization of the actual height of the DNA filament. Molecules scanned at minimal pressure can be locally destructed by scanning with a higher pressure, leading to the image of a "dissected" plasmid (Figs. $4 \mathrm{e}, \mathrm{f}) .\left({ }^{1}\right.$ )

The effect of the tip type can be demonstrated by comparing the quality of the images obtained with both tips operated in air. When compared to Fig. $4 \mathrm{c}$ (Digital Instruments $\mathrm{Si}_{3} \mathrm{~N}_{4}$ tip), images obtained with the Nanoprobe Si tip (Fig. 4g) were far better. Figures $4 \mathrm{~h}$ and $4 \mathrm{i}$ show, at identical magnifications, molecules scanned with a Si tip in propanol (Fig. 4h) and in air (Fig. 4i), the former condition being the best.

The contour length of the molecules was measured with a PC computer-driven digitizer, which showed that the size of the circular pBR322 is very reproducible $(1.446 \pm 0.028 \mu \mathrm{m}$ for 25 measurements on AFM images, at a magnification of 25,000 , according to the scale provided by the NanoScope, the actual size of this plasmid is $1.483 \mu \mathrm{m}$ for 4363 base pairs and $3.4 \AA /$ base pair). Similarly reproducible results were obtained by measuring the double-stranded circular replicating forms of $\phi \mathrm{X} 174$ bacteriophage. In specimens observed in air with a traditional $\mathrm{Si}_{3} \mathrm{~N}_{4}$ cantilever, the mean apparent height of DNA is about $1.4 \mathrm{~nm}$, and the apparent width about $22 \mathrm{~nm}$ (Fig. 4d). This discrepancy between the theoretical $2 \mathrm{~nm}$ diameter of DNA and the measured height and width is probably mainly due to the huge radius of curvature of the tip in relation to that of the molecules, as already discussed [8-12]. DNA molecules with an apparent width of about $13 \mathrm{~nm}$ are obtained with Si tips operated in air (Fig. 4i), and $10 \mathrm{~nm}$ when these Si tips are used in a propanol (Fig. $4 \mathrm{~h})$. Even smaller values $(8 \mathrm{~nm})$ have been obtained in air when using the "TappingMode" ${ }^{\mathrm{TM}}$ " (Fig. 4j). Here the DNA filament presents a 12-16 nm roughly periodic structure which in fact does not correspond to the double helix pitch, but could represent the local accumulation of uranium clusters onto the DNA, as already observed on stained DNA molecules observed in dark-field TEM or STEM [43].

The observation in air with a Si tip of the rear face of a Pt/Ir/C replica in the repulsive mode shows the DNA molecules embedded in the metallic film, with a faint contrast (Fig. 4k). In the friction mode, the same field shows that the DNA is clearly visible, although the resolution is poor (Fig. 41).

STM observations. - The most simple procedure, which allowed the molecules to be clearly depicted (Figs. 5a, b), consisted in adsorbing the DNA onto the mica as described earlier for AFM observation, and covering it with a thin layer of $\mathrm{Pt} / \mathrm{C}$ or $\mathrm{Pt} / \mathrm{Ir} / \mathrm{C}$. The apparent height and width of the shadowed DNA are about 1.7 and $7.5 \mathrm{~nm}$, respectively.

If some conductivity can actually be obtained through uncoated DNA molecules deposited onto a conductive support such as $\mathrm{Pt} / \mathrm{C}$, then atomic resolution could be expected on such molecules. However the conditions used by Amrein et al. [44], who adsorbed recA-DNA complexes onto

Comparative TEM and AFM of DNA. a) Platinum/carbon replica of a sample similar to that shown on Fig. 3, detached from the mica, and observed in Electron Spectroscopic Imaging in a Zeiss 902 TEM. b-1) AFM of DNA. b) Observation in the deflection mode of a sample similar to that shown on Fig. 3 (NanoScope II equipped with a Digital Instruments $\mathrm{Si}_{3} \mathrm{~N}_{4}$ cantilever and operated in air) c). Observation in the repulsive mode of a similar preparation. d) 3D representation of an isolated molecule (Same operating conditions as for $\mathrm{c}$ ). e \& f) High magnification of a molecule scanned several times at low pressure (e), then at a higher pressure on a selected zone which appears to be destroyed when observed at lower magnification ( $f$ ) (Same operating conditions as for c). $g$ \& i) Observation in air with a NanoScope III equipped with a Nanoprobe Si tip (Note that $\mathrm{g}$ is the same magnification as $\mathrm{a}, \mathrm{b}$ and $\mathrm{c}$ ). $\mathrm{h}$ ) Observation in $\mathrm{n}$-propanol with a NanoScope III equipped with a Nanoprobe Si tip (Note that $\mathrm{h} \& \mathrm{i}$ are at the same magnification). j) Observation in the "TappingMode ${ }^{\text {TM" }}$ with a NanoScope III. The quality of this new imaging mode allows good images to be obtained at high magnification, with "only" about $8 \mathrm{~nm}$ for the apparent width of the DNA. $k$ \& 1) Observation in air with a Si tip of the rear face of a $\mathrm{Pt} / \mathrm{Ir} / \mathrm{C}$ replica showing the contact plane of the molecules with the mica. Repulsive mode (k), friction mode on the same zone (1). The scales represent $400 \mathrm{~nm}(\mathrm{a}, \mathrm{b}, \mathrm{c} \& \mathrm{~g}), 200 \mathrm{~nm}(\mathrm{~h}, \mathrm{i}, \mathrm{k} \& \mathrm{l}), 100 \mathrm{~nm}(\mathrm{e} \& \mathrm{f})$ or $60 \mathrm{~nm}(\mathrm{j})$. 

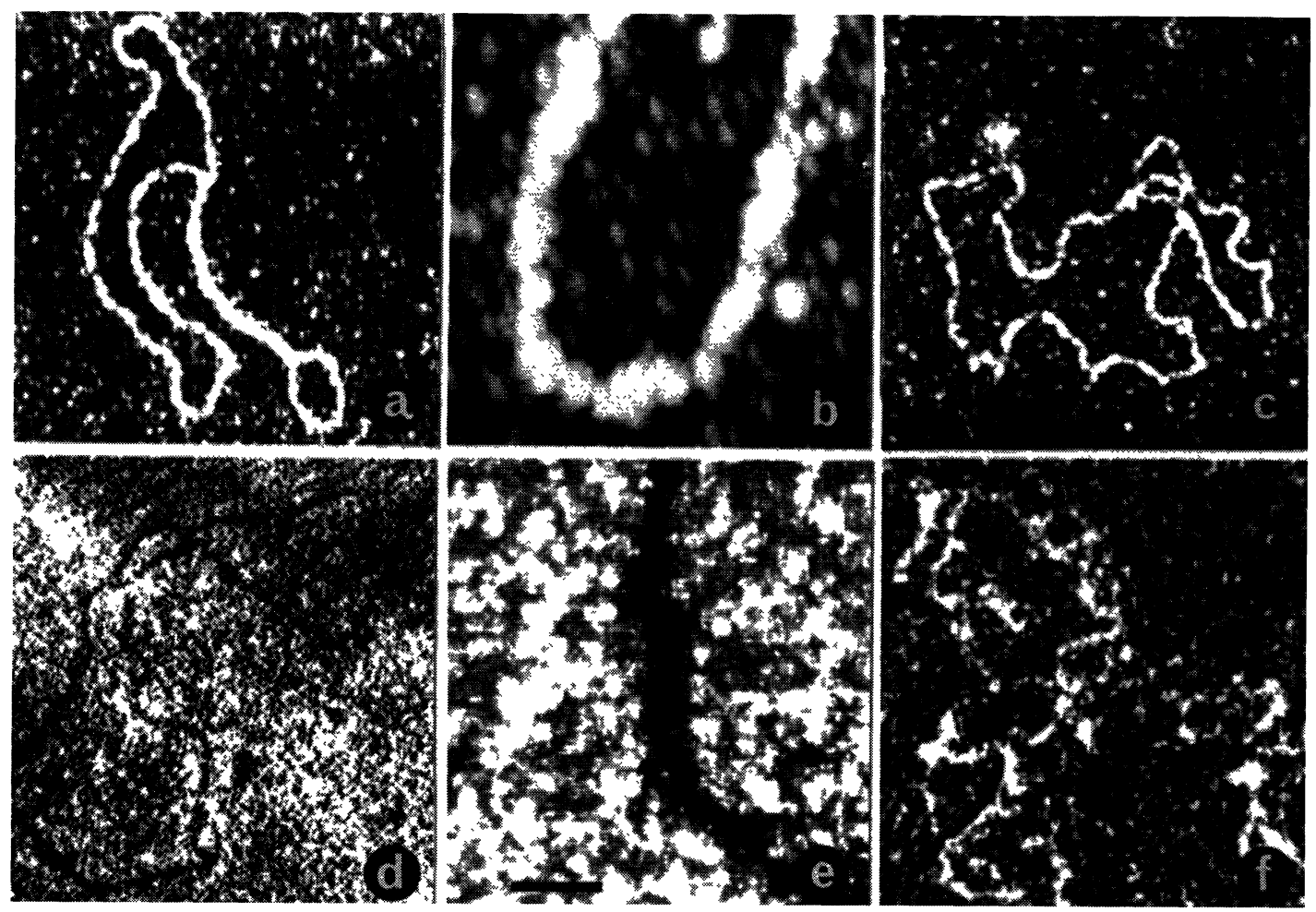

Fig. 5. - STM of DNA. a \& b) DNA molecules adsorbed onto mica as for Fig. 3 are covered with a thin layer of $\mathrm{Pt} / \mathrm{Ir} / \mathrm{C}$ and observed in a NanoScope II STM. Numerous molecules can be observed as shown in Fig. 3. With high magnification it is possible to show that the apparent width of the DNA is of the order of 7-8 $\mathrm{nm}$. c) As DNA adsorbed onto glow-discharged $\mathrm{Pt} / \mathrm{C}$ layer onto mica is non conductive, an additional layer of metal is necessary to see the molecules. $\mathrm{d} \&$ e) Observation of the rear face of a $\mathrm{Pt} / \mathrm{Ir} / \mathrm{C}$ replica showing in reverse contrast the contact plane of the molecules with the mica. High magnification shows the furrow-like image of the DNA molecule embedded in the conductive film. f) As DNA adsorbed onto glowdischarged HOPG is non conductive, the actual presence of the molecules is demonstrated by observing metallized samples. The scale represents $80 \mathrm{~nm}$ (a, c, d \& f) or $20 \mathrm{~nm}$ (b \& e).

$\mathrm{Pt} / \mathrm{C}$-coated mica with the help of $\mathrm{Mg}^{2+}$ could not be transported for naked DNA which did not bind to such a support; a glow discharge in the presence of pentylamine was necessary for its adsorption [42]. Unfortunately, this treatment makes the sample non conducting, and a thin metallization perpendicular to the mica substrate was necessary (Fig. 5c). This leads to background granularity which is greater than that obtained with DNA adsorbed onto coated mica (Fig. 5a). Nevertheless, the apparent size of the DNA (height: $2 \mathrm{~nm}$, width: $10 \mathrm{~nm}$ ) is only slightly higher than that obtained with a single metallization.

The observation of the mica bound surface of the DNA molecules embedded in a thick layer of $\mathrm{Pt} / \mathrm{Ir} / \mathrm{C}$ gives an image of the contact zone between the DNA and the mica. The molecules with no distinguishable fine structure, appear in negative contrast, indicating a weaker conductivity of the molecules compared to that of the conductive background (Figs. 5d, e). The width of these $1.8 \mathrm{~nm}$ deep furrow-like images is $2-4 \mathrm{~nm}$, although there is considerable roughness in relation to background granularity (Fig. 5e).

Before definitely rejecting HOPG as a potential support for the observation of DNA in STM, 
attempts were made to bind naked DNA to its surface as a control test. As expected, the results were similar to those for the carbon or $\mathrm{Pt} / \mathrm{C}$ support: no DNA bound unless a glow-discharge in the presence of pentylamine was applied. Such a sample was shadowed and showed the presence of DNA, even though the quality of the images was very unsatisfactory (Fig. 5f).

\section{Discussion.}

Our results with near-field microscopes of filamentous actin and double-stranded DNA molecules are in contradiction with many points raised in other published observations on identical or similar biological objects [8-18, 22, 23]. Mica pretreatment, either soaking in $\mathrm{MgCl}_{2}$, ultrasonic cleaning, washing or the use of a glow-discharge, was considered unnecessary for the binding of DNA onto the mica surface. The distribution of DNA all over the mica surface was both homogeneous and reproducible, with a solution concentration in the same range as that needed for TEM. No imaging problems were encountered with our samples when commercial $\mathrm{Si}_{3} \mathrm{~N}_{4}$ cantilevers were used, even if the sharper Nanoprobe Si tips gave better results, especially when operated in a liquid environment. No major observation or storage problems were encountered as a consequence of relative humidity. This problem of humidity, which has been extensively studied by some authors [15], should be considered fundamental, since it is difficult to know what is the actual conformation of a DNA or a protein molecule which has been dried on a substrate from a solution, in which salt and water retention have not been appraised. Selected areas on the mica surface could be scanned several times at various magnifications with only limited modifications of the initial aspect of the molecules. Molecules adsorbed onto mica can be "nanodissected" as already described by others [11-13], although we consider that the actual biological interest of such manipulation of the specimen is questionable.

As our intention was not to exhaustively examine the factors which intervene in DNA binding but merely to find a simple, reproducible recipe, our tests of different cations which promote DNA binding were limited in number. The use of cations has been proposed for this purpose, but many contradictory results have been found in the literature. For example $\mathrm{Al}^{3+}$, which did not work in our conditions, was used 20 years ago to bind DNA onto mica and was used recently for AFM purposes [45]. With $\mathrm{Mg}^{2+}$ or $\mathrm{Ca}^{2+}$ cations in the DNA solution and washing with very diluted uranyl salts, DNA molecules can be spread out in reproducible manner, similar to that observed during routine TEM observation of DNA attached to carbon films after glow-discharge treatment $[27,42]$. However we are unaware of whether the presence of $\mathrm{Mg}^{2+}$ or $\mathrm{Ca}^{2+}$ in the filamentous actin preparation promoted its easy binding to mica, since other tested proteins are able to bind without the need for these cations. It is obvious that the precipitation of DNA onto the support with uranyl salts helps molecules to spread out, but such a chemical agent should be avoided in the future when atomic resolution is achieved.

With regard to current knowledge concerning single-stranded DNA spreading, and its strong tendency to make secondary structures, it is difficult to imagine that such molecules will be visible as a straight single filament in the absence of drastic chemical or mechanical treatment. Published results show that even the use of formaldehyde [16] or formamide [17, H.G. Hansma, personal communication] does not lead to complete spreading. The use of cytochrome $c$ as an embedding material for the spreading of DNA [17] should be avoided since it obtructs the visualization of DNA itself. Assays with BAC, a detergent used to facilitate the spreading of DNA could be tested even if the already published images remain difficult to interpret [46]. Drying of a DNA solution deposited on mica $[15,47]$, the chemical modification of the surface [48] or electrodeposition [49, 50] still fail to provide satisfactory results, although double-stranded DNA and RNA molecules bind easily and reproducibly onto mica treated with 3-aminopropyltriethoxy silane (APTES) [18]. 
The best published AFM images of DNA have been obtained with specially designed super tips operated in a propanol environment $[12,13]$. We confirm the need for sharp tips and the help of propanol to image the molecules, although the apparent width of our DNA molecules obtained with Nanoprobe Si tips in air, was nearly twice as thin as that obtained with the traditional $\mathrm{Si}_{3} \mathrm{~N}_{4}$ cantilevers.

We were able to measure the length of plasmid DNA with very reproducible results, in contrast to some reports $[8,11,16]$. Similar faithful length measurements were also reported for RNA adsorbed onto APTES-treated mica [18]: the results were comparable to those obtained by traditional electron microscopy. Despite the conclusion of these authors, it must be kept in mind that the observation of stained molecules by dark-field in an electron microscope connected to a computer via a TV camera remains the most efficient system for the analysis of nucleic acid molecules and DNA-protein complexes [27]. Obviously, the digital acquisition of data is easily obtained with AFM or STM which will be a real competitor for electron microscopy in this field.

The visualization of either double- or single-stranded simple DNA molecules seems to pose problems for many people, and the use of TEM to test the spreading conditions is highly recommended $[9,10]$, since electron microscopy is still the reference method for imaging nucleic acid structures. Thus the attempts to observe unconventional nucleic acid structures directly by AFM $[46,47]$ or STM must still be considered premature.

Since highly corrugated specimens are not accessible to high resolution imaging, it was proposed that the surface of the object facing the substrate be imaged as the specimen is embedded in a conducting layer $[7,36,37]$. We have used this method to observe the contact surface between the $\mathrm{Pt} / \mathrm{Ir} / \mathrm{C}$ layer and the mica covered with actin filaments or DNA molecules, our results, which show that the material actually remains in the replica, and that the biological objects can be observed both in AFM and STM, confirm those already published [7,36]. The observation of the mica-bound surface of the DNA molecules embedded in a thick layer of $\mathrm{Pt} / \mathrm{Ir} / \mathrm{C}$ should allow us to image the contact zone between the DNA and the mica. We cannot affirm that binding and the detachment of the mica do not alter the biological molecule; however, the shadowing of the mica for control purposes, after its detachment from the $\mathrm{Pt} / \mathrm{Ir} / \mathrm{C}$ replica, demonstrated that the DNA had indeed been removed and was therefore embedded in the metallic layer. Measurement in STM of the apparent widths of DNA and actin filaments in these casts gave the smallest values, which were close to their actual diameter. The images of proteins and perhaps that of DNA could probably be enhanced if the shadowing conditions were optimized as described by Wepf et al. [35], using accurate thickness measurements of the metal deposited on lyophilized specimens.

The use of STM for the visualization of DNA adsorbed onto a support was rather difficult since spontaneous adsorption was obtained onto mica only, and a metal coating was needed to obtain a conductive preparation. Nevertheless, owing to the different modes of imaging of STM compared to AFM, the apparent width measurements in STM were often better than that obtained with AFM in the best conditions. If it is possible to obtain and understand conduction through biological specimens, then the use of conductive supports on which molecules are tightly bound by chemical grafting [52, E. Lesniewska personal communication], could be an alternative to metal coating, which is not compatible with atomic resolution.

Our attempts to visualize single-stranded DNA were rather disappointing mainly because such molecules have a strong tendency to collapse, even in the presence of denaturing agents. However the complexation of such molecules with specific single-stranded DNA binding proteins is a good stratagem to achieve their visualization, since preliminary experiments in TEM have shown a good visibility for single-stranded DNA partially complexed with single-strand binding proteins.

The reproducibility of either TEM, AFM or STM visualization of DNA or proteins, based on the recipes described herein indicates that this method can be applied rapidly with resolution enhancement procedures. Extensively described by others, these procedures involve the use of 
sharp styli and eventually of liquid-containing chambers for the scanning cell of the AFM, or recently developed machines using either non contact oscillating tips, or the "TappingMode ${ }^{\text {TM" }}$ developed by Digital Instruments.

\section{Acknowledgements.}

Some observations described in this paper are the results of our participation in the international Workshop organized by Mr Jean Fourmentin-Guilbert in November 1992 at the Royaumont Abbey (France): STM-AFM and Biological “Objects". Some results have already been presented at the last European Congress on Electron Microscopy in Granada (Spain) [53]. We thank A. Engel and A. Bremer for providing us with high quality actin filaments. Lorna Saint-Ange is thanked for critically reading the manuscript.

\section{References}

[1] BlOOMFIELd V.A. and ARSCOTT P.G., Nucl. Acids Mol. Biol. 5 (1991) 39-53.

[2] ARSCOTT P.G. and BLOOMFIELD V.A., Meth. Enzymol. 211A (1992) 490-506.

[3] CLEMMER C.R. and BEEBE T.P. Jr., Science 251 (1991) 640-642.

[4] HECKL W.M. and BINNIG G., Ultramicroscopy 42-44 (1992) 1073-1078.

[5] HANSMA P.K., Elings V.B., MARTI O. and BRACKER C.E., Science 242 (1988) 209-216.

[6] Engel A., Ann. Rev. Biophys. Biophys. Chem. 20 (1991) 79-108.

[7] BLACKFORD B.L., JERICHO M.H. and MULHERN P.J., Scanning Microsc. 5 (1991) 907-918.

[8] Bustamante C., Vesenka J., TANG C.L., Rees W., Guthold M. and Keller R., Biochemistry 31 (1992) 22-26.

[9] Zenhausern F., Adrian M., Ten Heggeler-Bordier B., EmCh R., Jobin M., TABORelli M. and DESCOUTS P., J. Struct. Biol. 108 (1992) 69-73.

[10] Zenhausern F., AdRiaN M., TEN Heggeler-BordieR B., ENg L.M. and Descouts P., Scanning 14 (1992) 212-217.

[11] Vesenka J., Guthold M., TANG C.L., Keller D., Delain E. and Bustamante C., Ultramicroscopy 42-44 (1992) 1243-1249.

[12] Hansma H.G., Vesenka J., Siegerist C., Kelderman G., MORRETt H., SinSHEIMER R.L., Elings V., Bustamante C. and HANSMA P.K., Science 256 (1992) 1180-1184.

[13] HENDERSON E., Nucl. Acids Res. 20 (1992) 445-447.

[14] GARCIA R., YUQIU J., SCHABTACH E. and BUSTAMANTE C., Ultramicroscopy 42-44 (1992) 1250-1254.

[15] ThUNDAT T., WARMACK R.J., AlliSON D.P., BOTTOMLEY L.A., LOURENCO A.J. and FERRELL T.L., J. Vac. Sci. Technol. A10 (1992) 630-635.

[16] HANSMA H.G., SinSHEIMER R.L., Li M-Q. and HANSMA P.K., Nuch Acids Res. 20 (1992) 3585-3590.

[17] YANG J., TAKEYASU K. and SHAO Z., FEBS Lett. 301 (1992) 173-176.

[18] LYUBCHENKO Y.L.L., JACOBS B.L. and LINDSAY S.M., Nuch Acids Res. 20 (1992) 3983-3986.

[19] ZENHAUSERN F., ADRIAN M., EMCH R., TABORELli M., JOBIN M. and DESCOUTS P., Ultramicroscopy 42-44 (1992) 1168-1172.

[20] ARAKAWA H., UMEMURA K. and IKAI A., Nature 358 (1992) 171-173.

[21] AMREIN M., DORR R., STASIAK A., GROSS H. and TRAVAGLINI G., Science 243 (1989) 1708-1711.

[22] Weisenhorn A.L., DRAKe B., Prater C.B., Gould S.A.C., HaNSMa P.K., OHNESORge F., Egger M., HEYN S-P. and GAUB H.E., Biophys. J. 58 (1990) 1251-1258.

[23] MaSai J., Shibata T., Kondo S. and Ishiwata S., J. Vac. Sci. Technol. B9 (1991) 1177-1179.

[24] AMREIN M., DÖR R., WinkLER H., TRAVAglini G., WePF R. and GrOSS H., J. Ultrastruct. Mol. Struct. Res. 102 (1989) 170-177.

[25] AMrEIN M., WANG Z. and GUCKENBERGER R., J. Vac. Sci. Technol. B9 (1991) 1276-1281.

[26] GuCKENBERger R., WiegräBE W., Hillebrand A., HARTMANN T., WANG Z. and BaUMeister W., Ultramicroscopy 31 (1989) 327-332. 
[27] Le Cam E., Theveny B., Mignotte B., Revet B. and Delain E., J. Electron. Microsc. Tech. 18 (1991) 375-386.

[28] HALl C.E., J. Biophys. Biochem. Cytol. 2 (1956) 625-629.

[29] HEUSER J., J. Electron Microsc. Tech. 13 (1989) 244-263.

[30] BEER M., BARTL P., KOLLER T. and ERICKSON H.P., Meth. Cancer Res. 6 (1971) 283-309.

[31] BRACK C., Crit. Rev. Biochem. 10 (1981) 113-169.

[32] Boisset N., TaVeau J-C., Pochon F., BarRay M., Delain E. and LaMy J.N., J. Struct. Biol. 106 (1991) 31-41.

[33] Púhler G., Weinkauf S., Bachmann L., MÚller S., Engel A., Hegerl R. and Baumeister W., EMBO J. 11 (1992) 1607-1616.

[34] Bremer A., Millonig R.C., SÚtterlin R., Engel A., Pollard T.D. and Aebi U., J. Cell Biol. 115 (1991) 689-703.

[35] WEPF R., AMREIN M., BÜRKLI U. and GROSS H., J. Microsc. 163 (1991) 51-64.

[36] BLACKFORD B.L. and JERICHO M.H., J. Vac. Sci. Technol. B9 (1991) 1253-1258.

[37] BUTT H-J., MƯlLER T. and GROSS H., personal communication.

[38] BAUER R., Meth. Microbiol 20 (1988) 113-146.

[39] Delain E., FourCade A., ReVET B. and MoRY C., Microsc. Microanal. Microstruct. 3 (1992) 175-186.

[40] WOlTER O., BAYER T. and GRESCHNER J., J. Vac. Sci. Technol. B9 (1991) 1353-1357.

[41] LAUNDON C.H. and GRIFFITH J.D., Biochemistry 26 (1987) 3759-3762.

[42] DubOCHET J., DuCOMMun M., ZOLLINGER M. and KELLENBERGER E., J. Ultrastruct. Res. 35 (1971) 147-167.

[43] MoRY C., Colliex C., ReVET B. and Delain E., Ultramicroscopy 2 (1981) 161-168.

[44] AMrein M., StaSiaK A., Gross H., Stoll E. and TraVAGlini G., Science 240 (1988) 514-516.

[45] WeISENhorn A.L., GaUb H.E., HaNSMa H.G., SinSHEIMER R.L., KELDERMAN G.L. and HANSMA P.K., Scanning Microsc. 4 (1990) 511-516.

[46] Cricenti A., Selci S., Chiarotti G. and Amaldi F., J. Vac. Sci. Technol. B9 (1991) 1285-1287.

[47] HENDERSON E., J. Microsc. 167 (1992) 77-84.

[48] Bottomley L.A., Haseltine J.N., Allison D.P., WaRmack R.J., Thundat T., Sachlenben R.A., BROWN G.M., WOYCHIK R.P., JACOBSON K.B. and FERRELL T.L., J. Vac. Sci. Technol. A10 (1992) 591-595.

[49] LindsaY S.M., TAO N.J., DeROSE J.A., Oden P.I., LyUbChenKo Y.L., HARRINGTON R.E. and SHALYAKHTENKO L., Biophys. J. 61 (1992) 1570-1584.

[50] Brown G.M., ALlison D.P., WARMACK R.J., JacobSON K.B., LARIMER F.W., WOYCHK R.P. and CARRIER W.L., Uttramicroscopy 38 (1991) 253-264.

[51] RadmaCher M., Tillmann R.W., FrITZ M. and Gaub H.E., Science 257 (1992) 1900-1905.

[52] ALLISON D.P., BOTTOMLEY L.A., THUNDAT T., BROWN G.M., WOYCHIK R.P., SCHRICK J.J., JACOBSON K.B. and WARMACK R.J., Proc. Natl. Acad. Sci. USA 89 (1992) 10129-10133.

[53] Delain E., FourCADE A., COUlaUd D. and MARTIN J.M., 10th European Congress on Electron Microscopy (Granada, S.pain, 1992) Volume 1, pp. 575-576. 